\title{
PELATIHAN PENGGUNAAN APLIKASI MICROSOFT OFFICE DALAM MENINGKATKAN PELAYANAN ADMINISTRASI BAGI PEGAWAI KANTOR DESA HARJATANI KRAMATWATU SERANG-BANTEN
}

\section{THE USAGE TRAINING OF MICROSOFT OFFICE APPLICATION IN IMPROVING ADMINISTRATION SERVICES FOR VILLAGE OFFICERS OF HARJATANI KRAMATWATU, SERANG - BANTEN}

\author{
Reni Haerani ${ }^{1}$, Rudi Repelita ${ }^{2}$ \\ ${ }^{I}$ Program Studi Manajemen Informatika, Politeknik PGRI Banten, Indonesia \\ ${ }^{2}$ Program Studi Teknik Elektronika, Politeknik PGRI Banten, Indonesia \\ ${ }^{1}$ renihaerani@politeknikpgribanten.ac.id, ${ }^{2}$ rudi@politeknikpgribanten.ac.id \\ $\underline{1} 087771283258,{ }^{2} 087848000191$
}

\begin{abstract}
Abstrak
Kegiatan Pengabdian Kepada Masyarakat pelatihan Microsoft Office ini bertujuan untuk memberikan keterampilan dan meningkatkan kemampuan pegawai Kantor Desa Harjatani dalam menggunakan dan memanfaatkan perangkat teknologi informasi khususnya mengenai sistem pelayanan administrasi masyarakat berbasis komputer. Permasalahan yang dihadapi pada Kantor Desa Harjatani adalah pegawainya dalam hal pelayanan administrasinya belum semua mengenal dan mengetahui bagaimana cara mengoperasikan aplikasi komputer, belum memanfaatkan dan juga belum mahir menggunakan program-program standar di komputer terutama Word, Excel dan Power Point. Metode pelaksanaan yang dilakukan berupa pelatihan, pegawai diberikan materi tentang pengetahuan dasar komputer serta materi Microsoft Office 2013 (Word, Excel dan Power Point) yang sering digunakan dalam kegiatan sehari-hari dalam pelayanan administrasi kepada masyarakat seperti pembuatan surat menyurat, pembuatan laporan administrasi, laporan kegiatan dan laporan keuangan. Pengabdian masyarakat ini diikuti oleh 10 orang pegawai Kantor Desa Harjatani, dan dilaksanakan selama 2 hari pada tanggal 15 dan 28 Agustus 2020. Hasil dari pelatihan Microsoft Office ini, pegawai mampu mengoperasikan komputer dalam pembuatan surat menyurat, administrasi Kantor Desa secara komputerisasi, mampu mengoperasikan Excel dalam pembuatan laporan keuangan dan mampu membuat presentasi dengan baik di Power Point. Dari kegiatan pelatihan yang dilakukan diharapkan dapat memberikan informasi, pengetahuan serta dapat membantu pegawai Kantor Desa Harjatani dalam peningkatan pelayanan administrasi.
\end{abstract}

Kata Kunci ; Pelatihan Komputer, Pelayanan Administrasi, Microsoft Office

\begin{abstract}
This Microsoft Office training community service activity aims to provide skills and improve the ability of Harjatani Village Office employees in using and utilizing information technology tools, especially regarding computer-based community administration service systems. This service activity in the form of computer training was carried out at the Harjatani Village Office. The problems faced by the Harjatani Village Office are that not all of the employees in terms of administrative services know and know how to operate computer applications, have not utilized and are also not proficient in using standard computer programs, especially Word, Excel and Power Point. The method of implementation is in the form of training, employees are given material on basic computer knowledge and Microsoft Office 2013 material (Word, Excel and Power Point) which are often used in daily activities in administrative services to the community such as writing correspondence, making administrative reports, activity reports and financial reports. This community service was attended by 10 employees of the Harjatani Village Office, and was held for 2 days on 15 and 28 August 2020. The results of this Microsoft Office training, employees are able to operate computers in writing correspondence, computerized Village Office administration, able to operate Excel in making financial reports and able to make good presentations on Power Point.From the training activities carried out, it is hoped that it can provide information, knowledge and can help employees of the Harjatani Village Office in improving administrative services.
\end{abstract}

Keywords; Computer Training, Administrative Services, Microsoft Office 


\section{PENDAHULUAN}

Teknologi informasi dan komputerisasi disaat ini sudah menjadi kebutuhan setiap instansi, baik swasta maupun pemerintahan. Penggunaan komputerisasi selain untuk mempermudah dalam penyimpanan data juga akan mempercepat dalam hal pelayanan. Kemampuan menggunakan dan memanfaatkan setiap perangkat teknologi informasi dan komunikasi merupakan salah satu faktor kunci untuk meningkatkan Sumber Daya Manusia pada setiap instansi. Setiap SDM perlu diberikan wawasan yang lebih dalam penggunaan teknologi informasi (Patria, 2020). Pegawai Kantor Desa Harjatani hanya beberapa saja yang sudah bisa memanfaatkan teknologi informasi ini, sedangkan perangkat desa diwajibkan untuk memberikan kinerja yang lebih dalam pelayanan administrasi kepada masyarakatnya. Salah satunya adalah UU Nomor 6 Tahun 2014 tentang Desa, pada pasal 26 ayat 1 dan 2 menjelaskan bahwa tugas utama Kepala Desa adalah untuk memimpin penyelenggaraan Pemerintah Desa. Jika SDM perangkat desa dapat bekerja dengan baik, maka akan baik pula dalam kinerja pelayanan administrasi desanya (Sormin et al., 2018).

Pemerintah telah menjadikan teknologi menjadi salah satu bekal kemampuan yang dapat dimanfaatkan oleh pendidikan dan masyarakat khususnya di desa. Penyebarluasan ilmu pengetahuan, teknologi dan seni sebagai produk seyogianya dapat dimanfaatkan oleh masyarakat (Pohan, 2017). Perangkat teknologi informasi dan komunikasi adalah salah satu faktor kunci untuk mengejar ketertinggalan SDM Indonesia dari bangsa-bangsa lain (Makmur, 2019). Program-program pendidikan dan pelatihan secara formal maupun non formal yang memberikan keterampilan dan kemampuan dalam menggunakan dan memanfaatkan perangkat teknologi informasi dan komunikasi menjadi prioritas kebutuhan (Rizki et al., 2014). Permasalahan yang dihadapi pada Kantor Desa Harjatani adalah pegawainya dalam hal pelayanan administrasinya belum semua mengenal dan mengetahui bagaimana cara mengoperasikan aplikasi komputer. Para pegawai belum memanfaatkan dan juga belum mahir menggunakan program-program standar di komputer terutama Microsoft Word, Microsoft Excel dan Microsoft Power Point. Padahal kebutuhan akan penguasaan komputer ini diperlukan bagi para pegawai Kantor Desa Harjatani untuk menunjang kegiatan administrasi dalam pelayanan kepada masyarakatnya sendiri (Hasibuan et al., 2020). Selain itu, tidak adanya pelatihan bagi pegawai secara rutin yang mampu mengajari para pegawai ini agar lebih menguasai keterampilan komputer. Kantor Desa Harjatani sendiri adalah salah satu 
kantor desa dari kumpulan 15 Desa dan pembagian wilayah administratif di bawah Kecamatan Kramatwatu Kabupaten Serang Provinsi Banten. Dengan alamat kantor Desa berada di Jl. Raya Serdang Waringin Kurung Harjatani Kecamatan Kramatwatu, Serang Banten 42161.

Berdasarkan analisis situasi dapat diidentifikasikan permasalahan mitra dalam program pelatihan keterampilan untuk membekali kompetensi pegawai Kantor Desa Harjatani yaitu sebagai berikut : (1) Pelatihan keterampilan aplikasi Microsoft Office khususnya Microsoft Word, Microsoft Excel dan Microsoft Powerpoint. Pelatihan tersebut bertujuan membantu para pegawai Kantor Desa Harjatani dalam melakukan kegiatan pencatatan dan administrasi data yang lebih baik ; (2) Sarana dan prasarana untuk mendukung pelatihan aplikasi Microsoft Word, Microsoft Excel dan Microsoft Powerpoint belum ada. Kantor Desa Harjatani belum memiliki ruangan khusus atau Laboratorium Komputer, akibatnya pelatihan keterampilan yang berhubungan dengan komputer belum dapat terlaksana; (3) Tenaga pengajar belum memiliki kualifikasi untuk melakukan pelatihan keterampilan aplikasi Microsoft Office khususnya Microsoft Word, Microsoft Excel dan Microsoft Powerpoint. Tidak adanya instruktur yang berkualifikasi untuk mengajarkan keterampilan Microsoft Office ini menghambat dalam melakukan pelatihan dan peningkatan keterampilan Microsoft Office.

Beberapa solusi yang dilaksanakan untuk memecahkan permasalahan mitra dalam hal ini pegawai Kantor Desa Harjatani, yaitu : (1) Menyelenggarakan keterampilan aplikasi Microsoft Office khususnya Microsoft Word, Microsoft Excel dan Microsoft Powerpoint yaitu berupa pelatihan ini diberikan kepada pegawai Kantor Desa Harjatani. (2) Menyediakan fasilitas ruangan atau laboratorium komputer untuk kegiatan pelatihan Microsoft Office khususnya Microsoft Word, Microsoft Excel dan Microsoft Powerpoint. (3) Menyediakan tenaga pengajar yang berkompeten untuk kegiatan pelatihan Microsoft Office khususnya Microsoft Word, Microsoft Excel dan Microsoft Powerpoint. Instruktur yang terlibat dalam pelatihan ini berjumlah 3 orang sesuai kapasitas kemampuannya.

Dalam hal penerapan komputerisasi pelayanan administrasi pemerintahan di level Desa ini juga harus memberikan yang terbaik guna membantu jalannya roda pemerintahan. Kemampuannya yang komplit membuat Microsoft Office menjadi pilihan utama bagi para pengguna komputer untuk menangani masalah bisnis maupun persoalannya dalam bidang 
pengolah kata, data, presentasi dan database (Sormin et al., 2018). Dengan adanya pelatihan komputer Microsoft Office ini diharapkan setiap orang dapat membuat laporan secara mandiri dan dapat menjadi pilot project bagi tugas diskusi dalam setiap hasil rapat (Kecil et al., 2009). Pelatihan adalah suatu proses yang dilakukan untuk mencapai kemampuan tertentu dalam rangka membantu mencapai tujuan organisasi dan diperlukan guna meningkatkan efisiensi, efektivitas serta produktivitas kerja yang terarah (Lodjo, 2013). Dan aplikasi Microsoft Office dapat membantu kinerja dalam membuat persuratan, pengadministrasian dan mempermudah pelayanan administrasi desa (Sulistyanto, 2017).

\section{METODOLOGI}

Kegiatan Pengabdian Masyarakat ini diberikan kepada pegawai Kantor Desa Harjatani Kramatwatu Serang-Banten dalam bentuk Pelatihan. Secara substansi kegiatan pelatihan ini selain memberikan pengetahuan dasar, cara mengerjakan dokumen dan presensi dengan menggunakan program Microsoft Office sehingga mencapai tujuan yang diharapkan. Adapun permasalahan mitra dan solusi yang diberikan dapat dilihat pada bagan berikut :

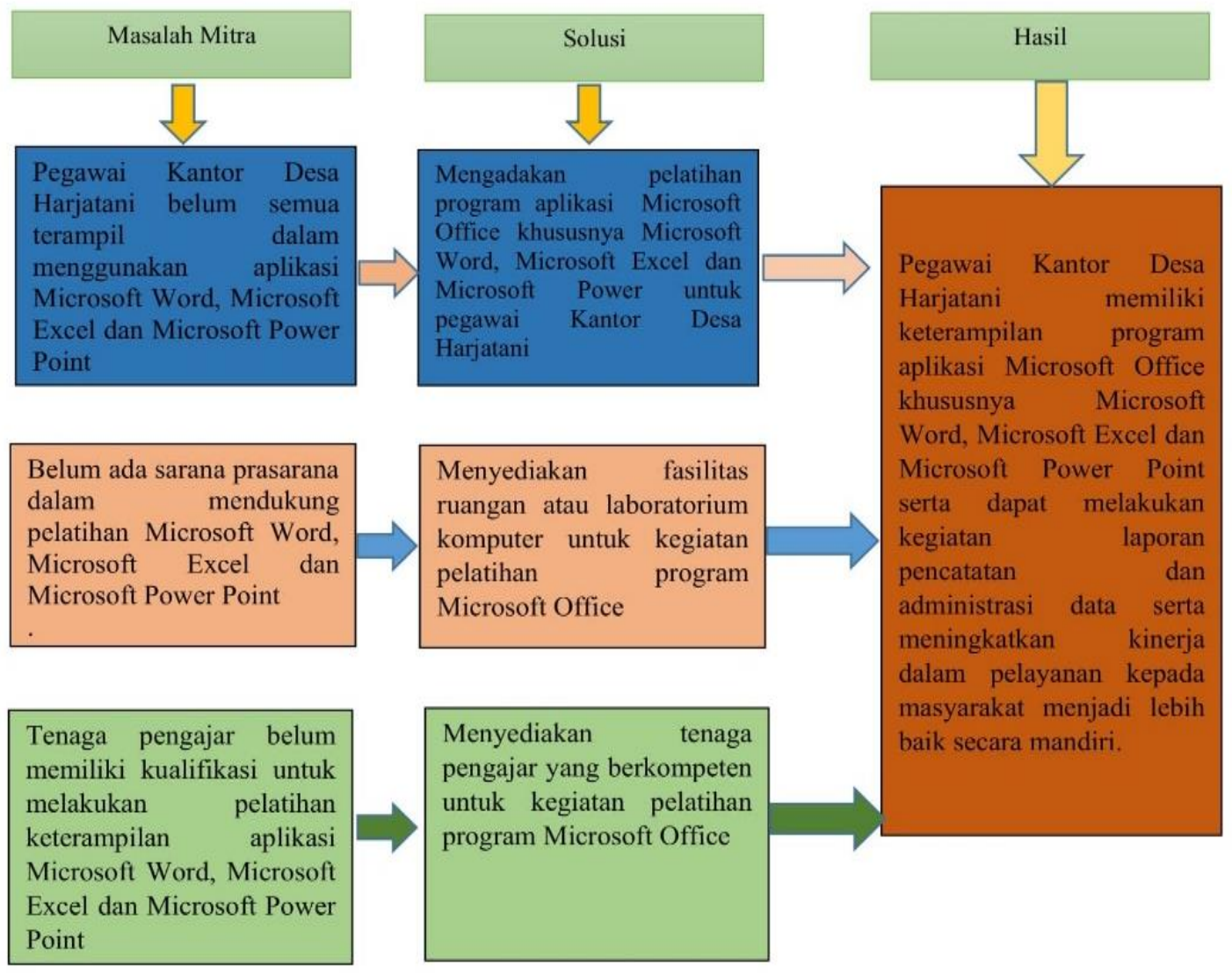

Figur 1. Bagan Permasalahan Mitra 
Sedangkan metode yang dilakukan dalam pelaksanaan pengabdian masyarakat ini adalah sebagai berikut :

a). Pengajaran

Metode yang digunakan untuk memberikan pengetahuan dan pemahaman mengenai cara pembuatan dokumen dan presentasi dengan metode pengajaran dan praktik langsung dilakukan di Kantor Desa Harjatani. Materi yang disampaikan dalam pengajaran dan praktik ini dimulai dengan memperkenalkan dan menjelaskan dasar komputer yang termasuk Hardware, Software dan Brainware. Hal ini untuk membuka wawasan mengenai interaksi dan responsi yang diperlukan antara ketiga komponen perangkat komputer tersebut. Peserta diberikan gambaran secara umum tentang setiap fungsi dari perangkat Hardware, Software dan Brainware dan hasil yang bisa dilihat pada layar dengan menerapkan praktik sederhana.

b). Tutorial (Pendampingan)

Peserta pelatihan diberikan pendampingan berupa operasi dan langkah sederhana untuk mencapai sebuah rancangan aplikasi yang sedang dibuat, contohnya mengatur warna latar belakang layar, mengatur halaman, mengatur paragraf, ukuran huruf/angka, cara bagaimana mencantumkan gambar atau teks. Selanjutnya mendampingi membuat laporan pada Microsoft Excel, rumus dasar pada excel seperti fungsi string, fungsi statistik, fungsi logika IF, dan memberikan pendampingan pembuatan slide presentasi pada Power Point. Peserta pelatihan juga diajak untuk mencoba memecahkan kasus yang sering timbul pada umumnya terjadi di seputar pengoperasian tombol komputer dan mengorganisir luaran yang diharapkan.

c). Diskusi

Peserta pelatihan diberikan kesempatan untuk mendiskusikan permasalahan yang berkaitan dengan penyelesaian aplikasi program yang sedang dibuat atau hal-hal yang berkenaan dengan topik yang sedang dikerjakan.

d) Tanya Jawab

Sebelum dilakukan presentasi materi, peserta pelatihan diberikan form questioner sebagai Pre Test bertujuan untuk melihat sejauh mana peserta memiliki pengetahuan terkait materi yang akan disampaikan. Sedangkan Post Test diberikan setelah selesai dilakukan materi sebagai umpan balik bagi tim pengabdian masyarakat. 


\section{PEMBAHASAN}

Pelaksanaan kegiatan Pengabdian Masyarakat dengan memberikan pelatihan Microsoft Office khususnya Microsoft Word, Microsoft Excel dan Microsoft Powerpoint pada Tanggal 15 dan 28 Agustus 2020 pukul 09.00 - 15.00 WIB yang diikuti oleh 10 pegawai yang dilaksanakan di ruangan utama pelayanan Kantor Desa Harjatani Kramatwatu Kabupaten Serang-Banten. Pelatihan berjalan sesuai dengan yang diharapkan. Hal ini dapat dilihat dari hari ke-1 dan ke-2. Adapun hasil yang diperoleh dapat ditunjukkan berdasarkan pelaksanaan yang dilakukan dengan pembahasan sebagai berikut :

\section{Pemberian Materi Pengenalan Komputer}
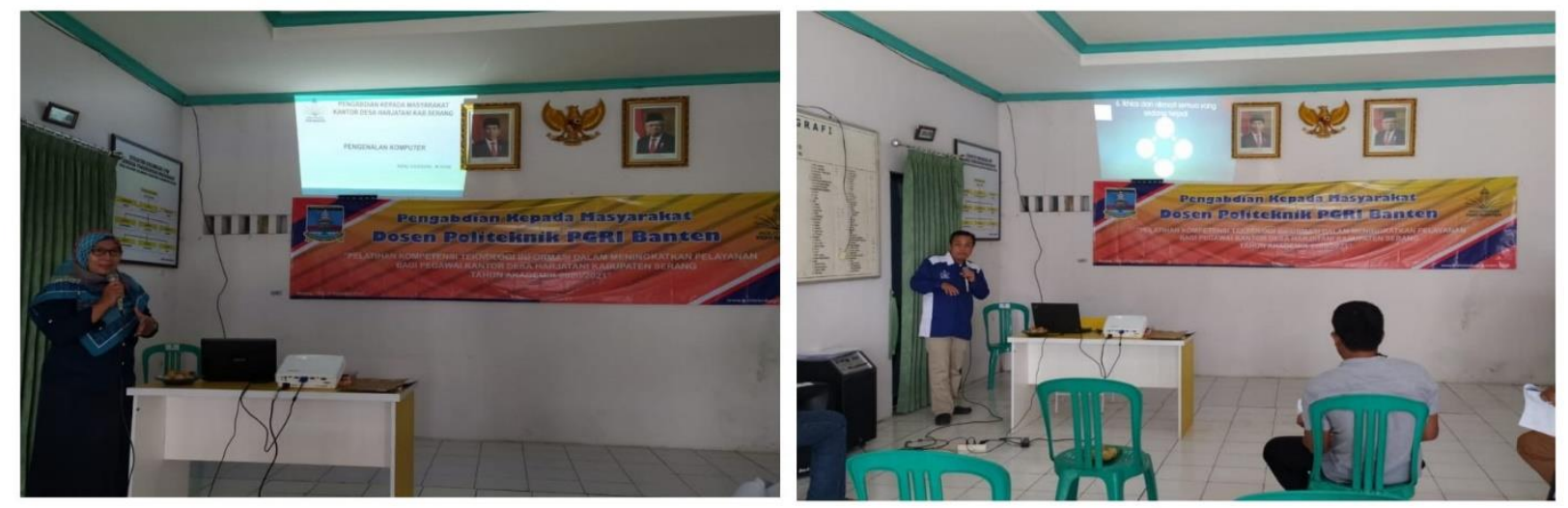

Figur 2. Pemberian Materi Pentingnya Teknologi Informasi

Kegiatan hari pertama yaitu tim pengabdian masyarakat memotivasi kepada pegawai Kantor Desa Harjatani terkait betapa pentingnya teknologi informasi khususnya komputer. Guna untuk memperlancar kinerja dan pelayanan administrasi masyarakat. Kegiatan ini dapat dikatakan terlaksana dengan baik hal ini didasari oleh antusias para peserta pelatihan dalam mengikuti kegiatan serta menambah informasi dan pengetahuan bagi peserta.

\section{Pemberian Materi Microsoft Office}

Kegiatan pelatihan pada hari kedua ini merupakan puncak dari kegiatan pelatihan karena membahas tentang praktek langsung aplikasi Microsoft Office (Word, Excel dan Power Point). Dengan materi pengenalan tool halaman pada word, membuat paragraf, membuat surat, membuat mail merge untuk persuratan, pembuatan surat keterangan dengan mail merge, sehingga memudahkan pegawai untuk mengadministrasikan surat-surat yang keluar, selanjutnya materi excel peserta mendapat keterampilan baru seperti cara menghitung dengan menggunakan rumus untuk penjumlahan dan pengisian auto input, fungsi-fungsi seperti, fungsi string, fungsi statistik, fungsi logika if, pembuatan tabel (Dhewy, 2018). 
Pada materi Microsoft Excel ini diharapkan para peserta mampu membuat laporan keuangan dengan memanfaatkan rumus-rumus pada excel agar tidak lagi manual untuk penghitungannya, sehingga dapat mengurangi kesalahan. Terakhir materinya adalah pengenalan Power Point, pada materi ini diajarkan bagaimana cara membuat presentasi yang baik, dengan membuat slide, effect dan lain-lain.
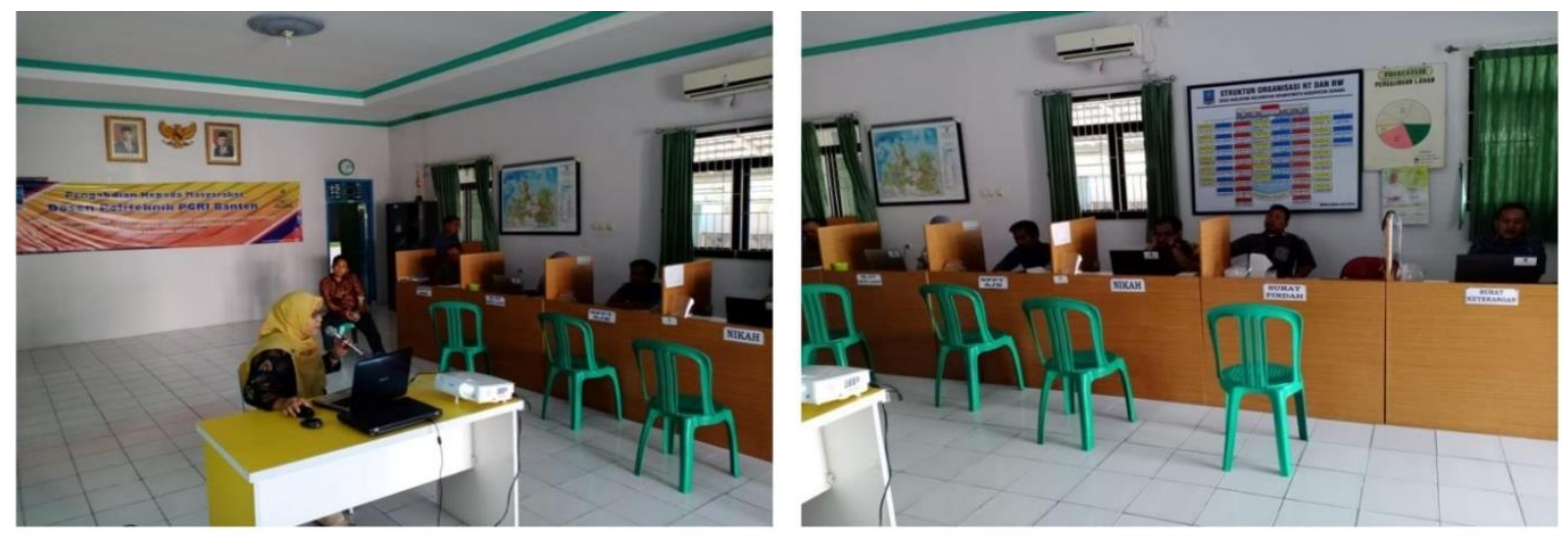

Figur 3. Pemberian Materi Microsoft Office

Berdasarkan hasil dari pengamatan dan hasil pelaksanaan maka kegiatan pelatihan ini memberikan hal-hal yang baru bagi para peserta pelatihan dan sekaligus memberikan manfaat yang besar untuk administrasi kantor desa, dimana sebelumnya para peserta belum pernah diberikan seminar atau pelatihan terkait teknologi Microsoft Office. Kegiatan ini dapat terlaksana dengan baik dan juga didasarkan pada antusias para peserta mengikuti kegiatan.

\section{Evaluasi Kegiatan}

Setelah materi selesai dilakukan, selanjutnya evaluasi dilakukan untuk alasan pengukuran terhadap target yang dicanangkan, wawasan dan pemahaman peserta khususnya Pegawai Kantor Desa Harjatani. Adapun evaluasi pertama diberikan dengan meminta umpan balik dari para peserta pelatihan berkaitan dengan materi yang telah disampaikan, dilakukan untuk mengetahui tingkat pengetahuan dan pemahaman mengenai aplikasi komputer yang sederhana. Hal ini diberikan untuk melihat apakah peserta pelatihan bisa mengerjakan aplikasi lanjut. Evaluasi kedua adalah melihat kemauan peserta pelatihan yang melebihi tingkat pengetahuan dan pemahaman mengatasi kendala diawal. Kemudian evaluasi ketiga adalah dengan melakukan observasi setiap luaran pada layar monitor pada setiap meja peserta pelatihan untuk melihat kecepatan operasioanl keyboard dan fungsi-fungsi yang ada yang sudah diberikan selama pelatihan. Terakhir evaluasi keempat adalah observasi kreatifitas yang berkembang setelah tingkat pemahaman bertambah selama kegiatan pelatihan. 


\section{Penutupan Pelatihan Microsoft Office}

Setelah acara selesai diakhiri dengan penutupan dan dilanjutkan dengan sesi foto bersama yang disajikan pada Figur 4. Berdasarkan hasil kegiatan berupa pelatihan Microsoft Office (Word, Excel dan Power Point) menunjukkan bahwa pengetahuan peserta dan keterampilannya dalam pengoperasian aplikasi mengalami peningkatan yang signifikan setelah diberikan ceramah dan praktik, sehingga pada kegiatan pelatihan tersebut terjadi diskusi dan tanya jawab yang sangat menarik.
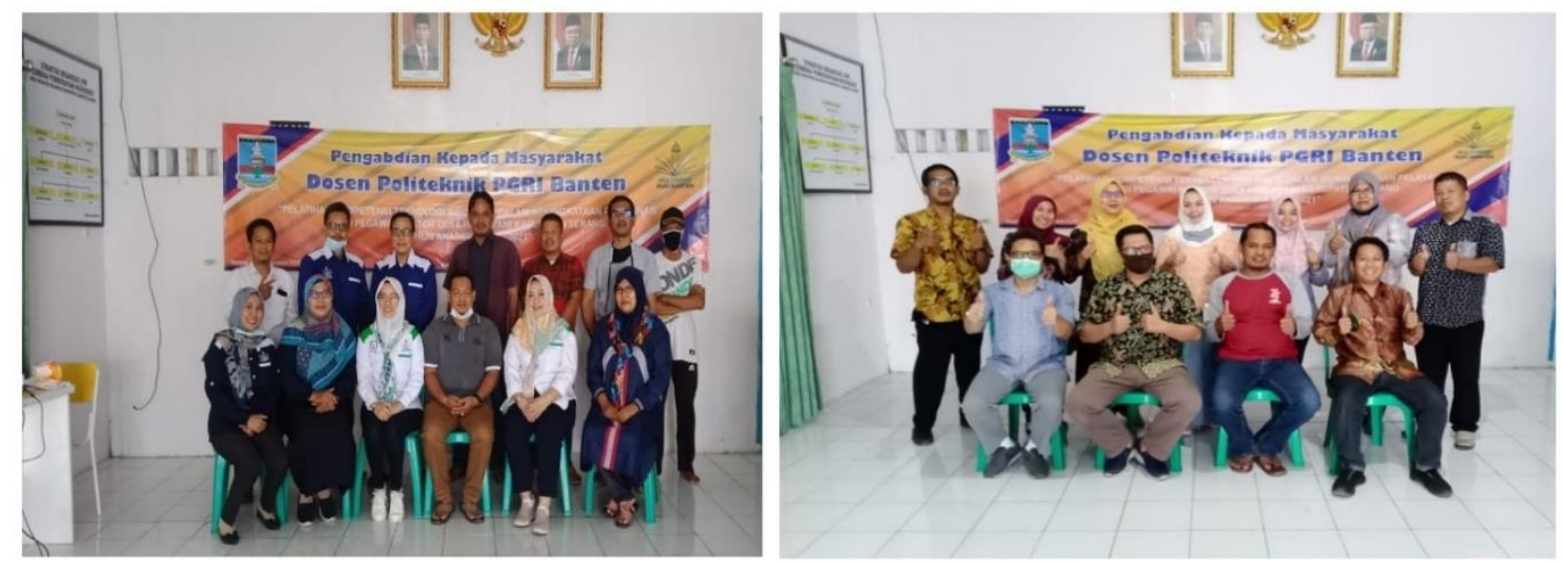

Figur 4. Penutupan Pelatihan Komputer Microsoft Office

Indikator yang digunakan sebagai tolak ukur meningkatnya pengetahuan dan pemahaman peserta adalah telah mampu dalam praktik pengolahan kata, data, presentasi dan database serta pelayanan administrasi yang digunakan saat kegiatan berlangsung. Disamping itu, respon positif terhadap kegiatan ini juga diberikan oleh peserta, hal ini terlihat dari pertanyaan peserta yang disampaikan pada saat diskusi. Pertanyaan tersebut mengindikasikan bahwa peserta memahami apa yang disampaikan oleh narasumber mengenai aplikasi Microsoft Office dan merupakan hal yang positif untuk pengetahuan tambahan yang berkualitas serta bermanfaat bagi peningkatan pelayanan administrasi desa kepada masyarakat.

\section{KESIMPULAN DAN SARAN}

Program pengabdian masyarakat melalui pemberian pelatihan penggunaan aplikasi Microsoft Office kepada pegawai Kantor Desa Harjatani berjalan dengan baik dan dapat disimpulkan sebagai berikut : 
1. Melalui kegiatan pengabdian kepada masyarakat dengan Pelatihan Microsoft Office, para peserta menambah wawasan tentang teknologi informasi, mengetahui perangkat hardware, software dan brainware.

2. Para peserta dapat membuat surat dengan mudah yaitu dengan cara mail merge, sehingga memudahkan data alamat juga tersimpan, dan juga dapat mengadministrasikan administrasi desa dengan komputerisasi.

3. Peserta dapat membuat laporan keuangan dengan Microsoft Excel dan memasukkan rumus fungsi sehingga lebih otomatis serta dapat membuat presentasi yang bagus.

4. Berdasarkan dari evaluasi kegiatan pengabdian kepada masyarakat ini diharapkan bisa berlanjut dengan perangkat desa dan terjalin kerjasama yang baik antara Politeknik PGRI Banten dan juga Kantor Desa Harjatani.

Berdasarkan kegiatan pengabdian kepada masyarakat yang telah dilakukan, maka terdapat beberapa saran terhadap pengembangan kegiatan pengabdian masyarakat selanjutnya. Beberapa saran pengembangan tersebut, yaitu untuk keberlanjutan kegiatan pengabdian masyarakat seperti ini bisa dengan memberikan beberapa pelatihan tambahan lainnya seperti kondisi ragam peserta, contohnya pelatihan untuk karang taruna, namun perlu ditetapkan jadwal serta program tepat guna yang dapat mempertemukan antara kebutuhan serta jadwal tim pengabdian masyarakat dengan jadwal kegiatan mitra sehingga pelaksanaan akan lebih optimal dan memberikan lebih banyak kontribusi bagi masyarakat.

\section{UCAPAN TERIMA KASIH}

Pengabdian ini terlaksana dengan bantuan berbagai pihak, terimakasih kepada pihak yang sudah membantu. UPPM Politeknik PGRI Banten dan Kepala Desa serta semua staf Kantor Kepala Desa Harjatani Kramatwatu Kabupaten Serang - Banten.

\section{REFERENSI}

Dhewy, R. C. (2018). Pelatihan Dasar-Dasar Statistika Dengan Menggunakan Aplikasi Microsoft Excel Di Sdn Pamotan Ii Kecamatan Porong. Jurnal PADI - Pengabdian MAsyarakat Dosen Indonesia, 1(1), 36-40.

Hasibuan, S., Rasal, A., \& Ashari, E. (2020). Pendampingan dalam Mewujudkan Budaya Tertib Arsip Informasi KTP dan KK di Kantor Kelurahan Pulau Abang, Provinsi Kepulauan Riau Jurnal Minda Baharu. 4(1), 20-31. https://doi.org/10.33373/jmb.v4i1.2336 
Kecil, I., Bordir, M., Ekonomi, F., \& Widyagama, U. (2009). Peningkatan Kinerja Melalui Orientasi Kewirausahaan, Kemampuan Manajemen, dan Strategi Bisnis (Studi pada Industri Kecil Menengah Bordir di Jawa Timur). Jurnal Manajemen Dan Kewirausahaan (Journal of Management and Entrepreneurship), 11(1), 46-58-58. https://doi.org/10.9744/jmk.11.1.pp.46-58

Lodjo, F. S. (2013). Pengaruh Pelatihan, Pemberdayaan Dan Efikasi Diri Terhadap Kepuasan Kerja. Jurnal Riset Ekonomi, Manajemen, Bisnis Dan Akuntansi, 1(3), 747-755. https://doi.org/10.35794/emba.v1i3.1882

Makmur, T. (2019). Teknologi Informasi. Info Bibliotheca: Jurnal Perpustakaan Dan Ilmu Informasi, 1(1), 65-74. https://doi.org/10.24036/ib.v1i1.12

Patria, P. D. (2020). JURPIKAT ( Jurnal Pengabdian Kepada Masyarakat ) Pelatihan Penggunaan Apkikasi Microsoft Office ( Word, Excel, Power point ) 2010 Untuk Peningkatan Kemampuan SDM PEMDES Desa. 1(1), 21-28.

Pohan, A,E. (2017). Program Pelatuhan Basic Of English Terhadap Anak-Anak Siswa Sekolah Dasar Di SDN 004 Sagulung. Jurnal Minda Baharu, 1(1), Hal. 7-14.

Rizki, M., Belakang, L., dan Negara, M. A. (2014). Kecamatan Tana Paser. 2(4), 18901901.

Sormin, M. A., Sahara, N., \& Agustina, L. (2018). Pelatihan Pemanfaatan Perangkat Lunak (Microsoft Office Word, Excel, Power Point) Dalam Kinerja Pengolahan Data Di Pemerintahan Desa Bagikepala Desa Se-Kecamatan Batang Angkola. Martabe : Jurnal Pengabdian Kepada Masyarakat, 1(2), 78. https://doi.org/10.31604/jpm.v1i2.78-82

Sulistyanto, H. (2017). Pakom Pelatihan Pengoperasian Komputer Bagi Perangkat Desa Di Kecamatan Gondangrejo Kabupaten Karanganyar. Warta LPM, 20(2), 111-119. https://doi.org/10.23917/warta.v20i2.4757 